\title{
ANALISIS KEKUATAN TARIK DAN BENDING KOMPOSIT SERAT KARBON-RESIN DENGAN VARIASI WAKTU CURING DAN SUHU PENAHANAN $80^{\circ} \mathrm{C}$
}

\author{
Eka Dwi Ratna Sari*, S.M. Bondan Respati dan Agung Nugroho \\ Jurusan Teknik Mesin, Fakultas Teknik, Universitas Wahid Hasyim \\ Jl. Menoreh Tengah X/22, Sampangan, Semarang 50236. \\ "Email: ekadwiratnasari2@gmail.com
}

\begin{abstract}
Abstrak
Berkembangnya teknologi industri dibidang otomotif dengan keterbatasan bahan baku material logam yang terkandung di alam mendorong material komposit banyak digunakan dan diaplikasikan dalam produk. Salah satunya adalah dengan memberi perlakuan curing. Curing merupakan proses perlakuan panas terhadap komposit untuk merubah resin memiliki daya ikat tinggi dengan serat ketika komposit telah padat. Tujuan dari penelitian ini adalah mengetahui nilai kekuatan tarik dan nilai kekuatan bending dari komposit serat karbon dengan resin lycal sebagai polimer yang diberi perlakuan curing pada waktu 1 jam, 1,5 jam, 2jam, 2,5 jam, dan 3 jam dalam penahanan suhu $80^{\circ} \mathrm{C}$. Dalam penelitian ini yang digunakan adalah serat carbon $3 K$ 240GSM resin yang digunakan adalah resin lycal GLR 1011. Komposit dibuat dengan menggunakan metode vacuum, diatas cetakan kaca berukuran $100 \mathrm{~cm}$ x $50 \mathrm{~cm}$. Cara pengambilan data adalah dengan melakukan ujian tarik dan bending pada komposit yang sudah di beri perlakuan curing dalam waktu 1 jam, 1,5 jam, 2 jam, 2,5 jam dan 3 jam dengan penahanan suhu $80^{\circ} \mathrm{C}$. Dari penelitian ini dapat diketahui bahwa nilai kekuatan tarik tertinggi pada komposit curing $80^{\circ} \mathrm{C}$ dengan waktu curing 1,5 jam didapatkan hasil tegangan tarik sebesar 629.799 Mpa yield stress 479.44 Mpa. Sedangkan nilai terendah yaitu pada komposit yang diberi perlakuan suhu curing $80^{\circ} \mathrm{C}$ dengan waktu curing 2 jam didapatkan hasil tegangan tarik sebesar 420.816 Mpa yield stress 462.212 Mpa. Nilai tegangan bending terbesar pada komposit curing $80^{\circ} \mathrm{C} 1$ jam yaitu 840.915 Mpa dan sedangkan nilai tegangan bending terendah di 3 jam sebesar 1008.670 Mpa.
\end{abstract}

Kata kunci: Komposit, Karbon, Resin, Uji Tarik, Uji Bending

\section{PENDAHULUAN}

Berkembangnya teknologi industri dibidang otomotif dengan keterbatasan bahan baku material logam yang terkandung di alam mendorong material komposit banyak digunakan dan diaplikasikan dalam produk. Komposit merupakan salah satu jenis rekayasa material yang bertujuan untuk mendapatkan sebuah material baru, komposit berasal dari kata to compose yang memiliki arti menggabung. Jadi komposit adalah material yang terbentuk dari kombinasi dua atau lebih material, dimana sifat mekanik dari material pembentuknya berbeda-beda (Jones, 1975).

Serat mempunyai sifat sebagai isolator yang baik, memiliki kekuatan, suhu tinggi dan memiliki regangan yang rendah. Geopolimer merupakan salah satu material yang dapat digunakan untuk memenuhi kebutuhan tersebut adalah. Geopolimer merupakan polimer anorganik yang memiliki kekuatan mekanik yang lebih baik, tahan terhadap suhu tinggi dan zat asam (Abdel-Ghani et al, 2016; Schmücker and MacKenzie, 2005). Geopolimer berperilaku seperti keramik yang keras tetapi dengan kuat lentur dan kuat tarik yang rendah. Kelemahan tersebut dapat diatasi dengan menambahkan material sisipan yang dapat berfungsi sebagai penguat (agregat) (Rustan dkk., 2015). Salah satu bahan sisipan yang dapat ditambahkan pada pasta Geopolimer adalah serat karbon.

Serat karbon adalah serat sintesis dengan kekuatan tarik dan konduktivitas listrik yang tinggi, massa jenis serta koefisien ekspansi termal yang rendah membuatnya sangat populer di bidang Industri. Dalam industri otomotif perkembangan dari bahan yang akan digunakan sebagai komponen kendaraan bermotor sudah sangat maju, hal ini dibuktikan dengan berbagai macam variasi bahan yang lebih ringan dan kuat namun tetap memenuhi aspek keamanan untuk komponen kendaraan tersebut. Rekayasa dibidang material tidak bisa dihindarkan di zaman yang modern ini bahkan sudah sangat maju. Hal itu menyebabkan kebutuhan akan komponen berbahan ringan namun kuat akan terus meningkat. Salah satu bahan yang biasa digunakan untuk melakukan rekayasa material adalah serat karbon. 
Bahan konstruksi untuk body kendaraan atau beberapa komponen pada kendaraan apabila menggunakan serat karbon akan menjadi sangat ringan, hal itu dapat menjadikan berat kendaraan menjadi ringan namun tetap kuat. Dengan menggunakan komposit serat karbon juga akan memaksimalkan performa kendaraan. Dalam kasus lain komposit serat karbon juga digunakan sebagai bahan untuk membuat mobil hemat energi, karena memiliki berat yang sangat ringan namun kuat maka berat mobil juga berkurang drastis. Semakin ringan mobil semakin sedikit pula konsumsi bahan bakar yang terpakai karena mesin tidak membawa beban yang berat. Oleh karna itu dalam pengujian ini, untuk memilih serat karbon yang digunakan dalam pengujian tugas akhir untuk mengetahui secara langsung bagaimana hasil kekuatan tarik dan bending dari serat carbon sendiri.

Material komposit ini dibuat dengan cara mencampur resin lycal dengan catalist yang secara teoretis akan meningkatkan modulus elastisitas. Untuk meningkatkan kekuatan ikatan paduannya maka proses curing dilakukan dengan variasi temperatur dan waktu penahanan (Holding time) tertentu. Tujuan dilakukannya curing dengan temperatur dan waktu tertentu adalah untuk memperbaiki sifat mekanik komposit material dan juga untuk menghilangkan tegangan sisa pada komposit, sehingga diharapkan kekuatannya akan meningkat. Dalam pengujian Nurcahyo $d k k$. 2004) menguji variasi temperature curing yang dapat membuat kekuatan tarik menjadi optimal.

Pengujian yang dilakukan oleh Bernard Korompis (2005) didapatkan variasi jumlah serat meningkatkan kekuatan tariknya. Komposit memiliki tujuan agar meminimalisir berat suatu komponen, namun tetap memiliki kekakuan dan kekuatan yang tinggi. Banyak variasi untuk matriks dan polimer yang digunakan dalam komposit dari uraian diatas, penggunaan karbon sebagai matriks dan resin sebagai polimer merupakan sebuah gagasan untuk mendukung perkembangan teknologi di bidang material teknik. Tujuan penelitian pada tugas akhir ini adalah mengetahui pengaruh variasi waktu curing komposit carbon fiber terhadap kekuatan tarik, kekuatan bending dan struktur makro komposit carbon fiber.

\section{METODE PENELITIAN}

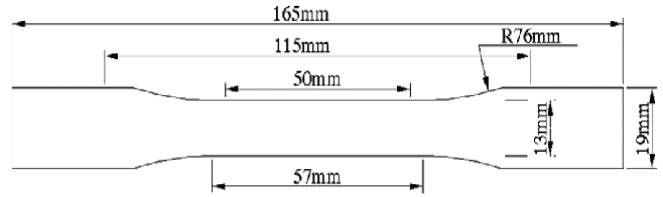

\section{Gambar 1. Spesimen ASTM D638 tipe I}

Carbon fiber yang digunakan peneliti memiliki jenis anyaman Tail $2 / 2$ mempunyai jumlah 3000 filament/untaian serta mempunyai berat $240 \mathrm{~g} / \mathrm{m}^{2}$ dan pada tiap $1 \mathrm{~cm}$ terdapat 6 benang. Jenis resin yang digunakan dalam pembuatan benda uji adalah jenis resin lycal GLR 1011 keras dengan merk dagang Lycal yang akan dicampur dengan pengeras catalist Lycal dengan kode GLR 1011 yang berfungsi sebagai matrik pada komposit. Proses curing dengan waktu 1 jam, 1,5 jam, 2 jam, 2,5 jam dan 3 jam dengan penahanan suhu $80^{\circ} \mathrm{C}$. Pengujian yang dilakukan adalah pengujian tarik sesuai standar ASTM D638 tipe 1 (lihat Gambar 1.), pengujian Bending berdasarkan standar ASTM C393 (lihat gambar.2), dan foto makro dari komposit yang sudah diberikan perlakuan curing.

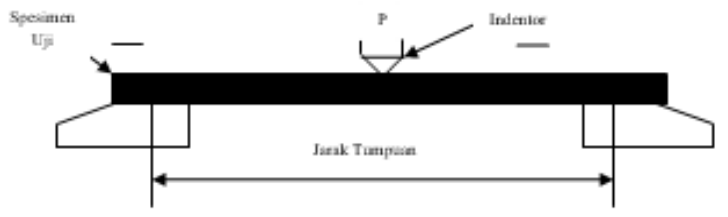

Gambar 2. Uji bending (Wijoyo, 2014)

$\begin{array}{ll}\text { Panjang } & =100 \mathrm{~mm} \\ \text { Lebar } & =30 \mathrm{~mm} \\ \text { Tebal } & =\text { Sesuai komposit yang dibuat }\end{array}$

\section{HASIL PEMBAHASAN \\ Pengujian Tarik}

Hasil pengujian tarik komposit serat karbon-resin tanpa perlakuan suhu curing dan yang diberi perlakuan suhu curing pada suhu $80^{\circ} \mathrm{C}$ dengan waktu curing 1 jam, 1,5 jam, 2 jam, 2,5 jam, dan 3 jam. Hasil pengujian tarik disajikan dalam Gambar 3. Nilai uji tarik tertinggi pada komposit serat karbon - resin yang diberi perlakuan suhu curing pada suhu $80^{\circ} \mathrm{C}$ dengan waktu perlakuan curing 1,5 jam didapatkan hasil tegangan tarik sebesar 629.799 Mpa yield stress 479.44 Mpa. Sedangkan pengujian paling rendah yaitu pada komposit serat karbon-resin yang diberi perlakuan suhu 
curing $80^{\circ} \mathrm{C}$ dengan waktu curing 2 jam didapatkan hasil tegangan tarik sebesar 420.816 Mpa yield stress 462.212 MPa.

Uji Tarik aYield Stress (MPa) @ Max. Stress (MPa)

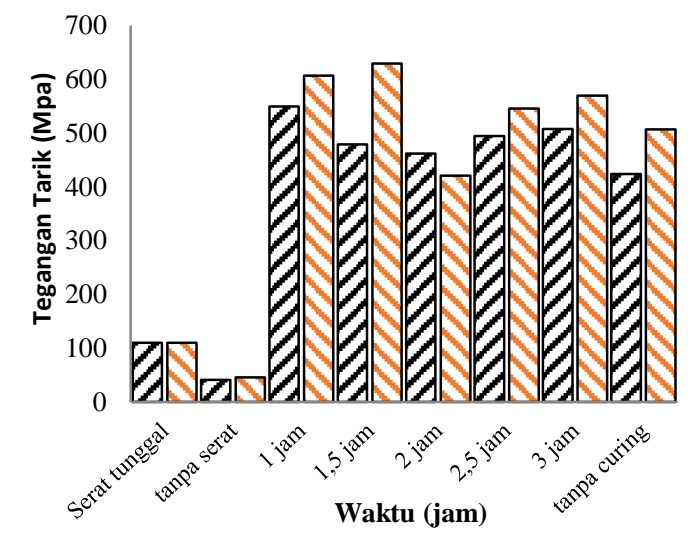

Gambar 3. Grafik tegangan uji tarik

\section{Pengujian bending}

Pengujian bending dilakukan di laboratorium perancangan UNWAHAS. pengujian dilakukan sebanyak 3 kali pada masing-masing spesimen. Hasil pengujian bending komposit serat karbon-resin diberi perlakuan curing pada suhu $80^{\circ} \mathrm{C}$ dengan waktu 1 jam 1,5 jam 2 jam 2,5 jam dan 3 jam dapat dilihat pada gambar 4 .

Hasil pengujian bending tertinggi pada komposit karbon-resin tanpa curing 3 jam didapatkan nilai 1008.670 Mpa sedangkan nilai terendah terdapat pada komposit karbon-resin curing 1 jam dengan nilai $840.915 \mathrm{MPa}$. Perbedaan temperatur post-curing waktu penahanan suhu $80^{\circ} \mathrm{C}$ pengujian bending komposit karbon berpengaruh terhadap stabilnya nilai tegangan bending.

Semakin lama waktu perlakuan curing menjadikan komposit karbon-resin mendapatkan tegangan bending yang baik. Stabilnya hasil kekuatan bending bisa disebabkan jenis resin yang digunakan untuk proses curing. pada resin lycal, perlakuan curing pada suhu $80^{\circ} \mathrm{C}$ dengan waktu 1 jam, 1,5 jam, 2 jam, 2,5 jam dan 3 jam didapatkan hasil optimal pada perlakuan curing dengan waktu 3 jam dan terendah di perlakuan curing dengan waktu 1 jam. Pada perlakuan tanpa curing didapatkan hasil tertinggi $4640.099 \mathrm{MPa}$ dikarenakan penggunaan dari resin lycal yang bersifat menguap jika terlalu lama dipanaskan. Sehingga spesimen tanpa perlakuan curing mendapat hasil pengujian bending yang paling tinggi.

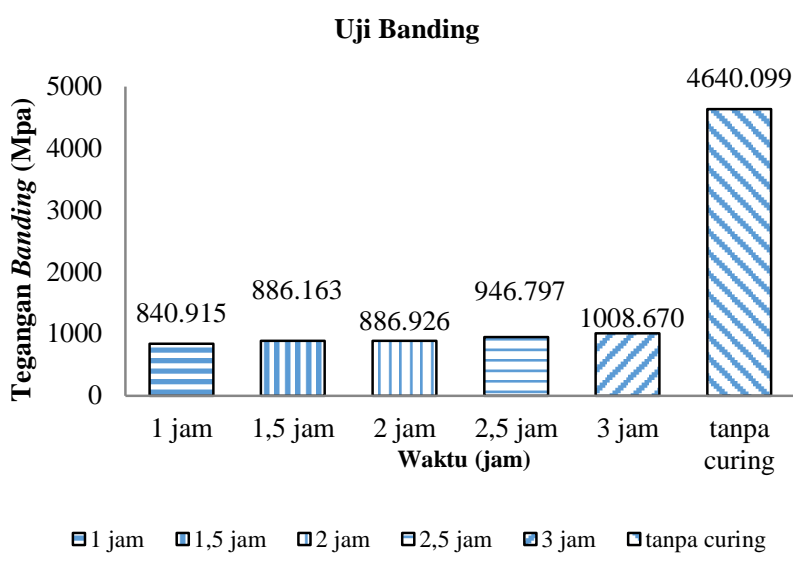

Gambar 4. Grafik uji bending

\section{Foto patahan}

Dari hasil uji tarik pada komposit serat karbon-resin lycal 1011 dapat dilihat dari hasil foto mikro patahan-patahan uji tarik tanpa curing, 1 jam, 1,5 jam, 2 jam, 2,5 jam, dan 3 jam dalam penahanan suhu $80^{\circ} \mathrm{C}$ seperti pada Gambar berikut:

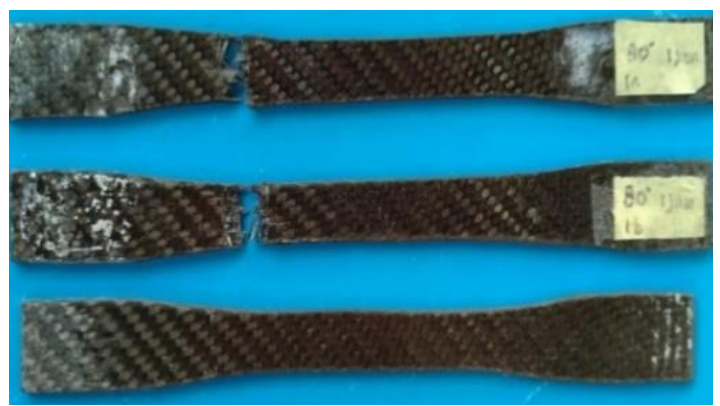

Gambar 5. Foto patahan spesimen pengujian tarik $80^{\circ} \mathrm{C} 1$ jam

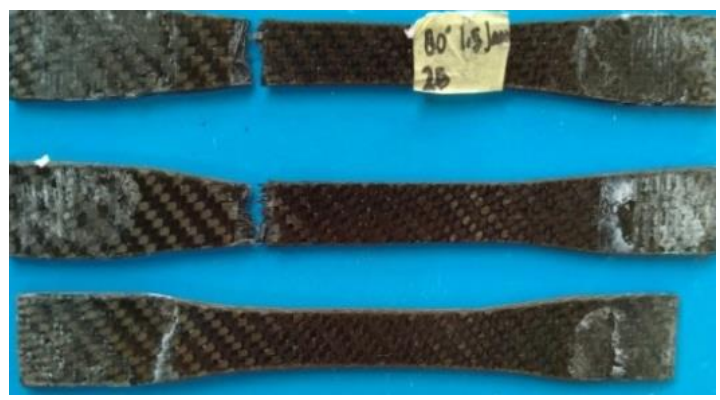

Gambar 6. Foto patahan spesimen pengujian tarik $80{ }^{\circ} \mathrm{C} 1,5$ jam 


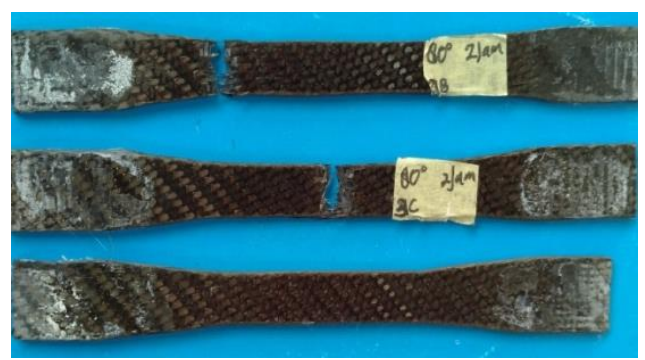

Gambar 7. Foto patahan spesimen pengujian tarik 80 ${ }^{\circ} \mathrm{c} 2$ jam

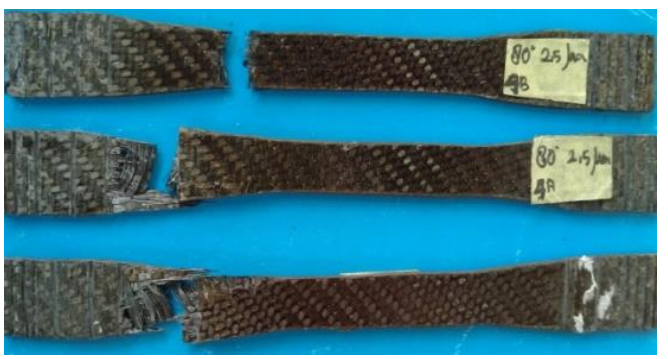

Gambar 8. Foto patahan spesimen pengujian tarik $80^{\circ} \mathrm{c} 2,5$ jam

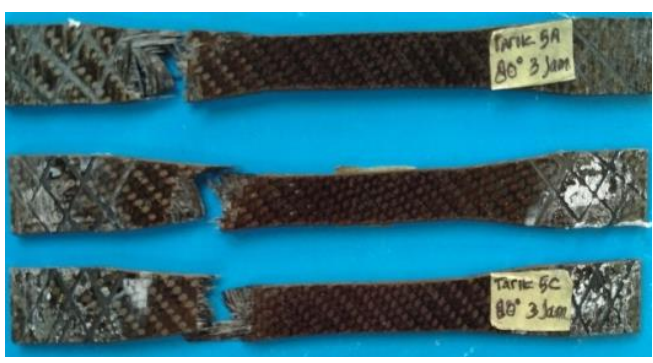

Gambar 9. Foto patahan spesimen pengujian tarik $80^{\circ} \mathrm{C} 3$ jam

\section{Hasil foto patahan}

Dari hasil foto patahan dapat dilihat bahwa semakin lama waktu curing, resin pada komposit akan mengalami penguapan. Yang membuat potongan semakin lama tidak rapi. Sehingga dapat di simpulkan bahwa waktu curing berpengaruh baik dalam komposit, tetapi semakin lama waktu caring belum tentu juga mendapatkan nilai yang baik karna resin akan mengalami penguapan yang membuat potongan tidak rapi. Jadi perlu waktu yang tepat untuk mendapatkan nilai tegangan tarik yang baik.

\section{Pengaruh curing terhadap densitas}

Pengaruh terhadap densitas yang telah dilakukan pada komposit serat karbon resin yang diberi perlakuan curing dalam waktu 1 jam, 1,5 jam, 2 jam, 2,5 jam dan 3 jam dengan penahanan suhu $80^{\circ} \mathrm{C}$ dapat dilihat hasil seperti pada tabel 3 sebagai berikut:

Tabel 1. Tabel hasil rata-rata pengaruh curing terhadap densitas

\begin{tabular}{llcc}
\hline No & Material & $\begin{array}{l}\text { Waktu curing } \\
\text { (jam) }\end{array}$ & $\begin{array}{l}\text { Berat jenis } \\
\text { gr/cm }\end{array}$ \\
\hline 1 & Komposit & Tanpa curing & 1.51 \\
2 & Komposit & 1 jam & 1.355 \\
3 & Komposit & 1.5 jam & 1.393 \\
4 & Komposit & 2 jam & 1.324 \\
5 & Komposit & 2.5 jam & 1.355 \\
6 & Komposit & 3 jam & 1.328 \\
\hline
\end{tabular}

Dari data yang diperoleh dapat disimpulkan bahwa perlakuan variasi waktu curing terhadap komposit serat karbon berpengaruh terhadap densitas dari komposit untuk sendiri, karena ada pengaruh fraksi volume.

Dapat dilihat dari Gambar 5- 9 foto makro spesimen hasil pengujian tarik dapat dilihat bahwa komposit serat karbon-resin banyak perbedaan mulai dari hasil patahan, perubahan warna spesimen. Yang menyebabkan perbedaan hasil pengujian tarik dan banding yang di buktikan Tabel 1 Menunjukkan hasil pengujian tarik serat karbon curing dan Tabel 2 Menunjukkan Hasil pengujian bending serat karbon curing.

Saat melakukan uji tarik tanpa curing menghasilkan nilai 506.835 MPa dan Yield Stress $423.933 \mathrm{MPa}$, kemudian spesimen diberi perlakuan curing dengan penahanan suhu $80 \mathrm{oC}$ dengan waktu curing 1 jam, 1,5 jam, 2 jam 2,5 jam dan 3 jam menghasilkan nilai kekuatan tarik bertambah dari pengujian tanpa perlakuan curing. Hal ini disebabkan pada proses caring resin masuk ke dalam rongga-rongga serat karbon dan mengikat serat karbon, kemudian pada waktu curing 1 jam $80^{\circ} \mathrm{C}$ menghasilkan pengikatan antara resin dan serat karbon di buktikan dengan nilai kekuatan tarik 606.967 MPa dan Yield Stress 549.815 MPa pada waktu 1 jam nilai Yield Stress tertinggi, kemudian pada waktu 1,5 jam $80 \mathrm{oC}$ nilai Yield Stress menurun dan nilai kekuatan tarik tertinggi di waktu curing 1,5 jam dengan nilai 479.44 yield stress MPa dan kekuatan tarik 629.799 MPa.

Pada perlakuan waktu 2,5 jam dibandingkan dengan waktu 3 jam yang menurun hal ini disebabkan waktu curing terlalu lama sehingga resin yang mengikat serat 
mengalami penguapan dibuktikan dengan nilai fraksi volume yang menurun. Tetapi pada perlakuan curing 2 jam menurut pengamatan penyebab terjadinya penurunan nilai kekuatan tarik pada waktu proses pengujian terjadinya slip pada pemegang spesimen yang berada di alat uji tarik, karna pemegang spesimen tersebut di desain buat material logam jadi waktu pengujian spesimen ditambah plat besi untuk memperkuat pegangan pada spesimen.

Pada uji banding mengalami penurunan pada hasil uji bending yang disebabkan oleh beberapa hal, yang pertama saat proses curing spesimen mengalami perubahan sifat menjadi keras dibandingkan dengan tanpa curing dari sifat keras tersebut menjadikan spesimen lebih getas dan mudah patah, yang kedua saat proses curing terjadi penyusutan pada volume spesimen yang mengakibatkan turunnya hasil pengujian banding, dibuktikan pada Gambar 11 Grafik pengaruh curing terhadap densitas.

\section{KESIMPULAN}

Dari penelitian komposit karbon-resin yang diberi perlakuan curing ini dapat di ketahui bahwa:

1. Hasil pengujian tarik tertinggi pada komposit serat karbon-resin yang diberi penahanan suhu $80^{\circ} \mathrm{C}$ dengan waktu perlakuan curing 1,5 jam didapatkan hasil tegangan tarik sebesar 629.799 Mpa yield stress 479.44 MPa. Hal tersebut disebabkan karna metrik dan karbon dapat saling mengikat lebih rapat karna perlakuan curing sehingga dapat meningkatkan kekuatan tarik pada komposit. Sedangkan pengujian paling rendah yaitu pada komposit serat karbonresin yang diberi perlakuan suhu curing $80 \mathrm{oC}$ dengan perlakuan waktu curing 2 jam didapatkan hasil tegangan tarik sebesar 420.816 Mpa yield stress 462.212 Mpa. Jadi variasi waktu curing pengujian tarik komposit karbon berpengaruh baik pada komposit karbon-resin ketika diuji suhu $80 \mathrm{oC}$ dengan waktu curing 1,5 jam, apabila komposit diberi perlakuan curing dengan waktu yang tepat maka akan mendapatkan nilai kekuatan tarik yang optimal. Namun semakin lama perlakuan curing belum tentu menjadi komposit karbon-resin mendapatkan nilai yang baik.

2. Hasil pengujian bending tertinggi pada komposit serat karbon-resin tanpa perlakuan curing didapatkan hasil tertinggi
4640.099 MPa dikarenakan penggunaan dari resin lycal yang bersifat menguap jika terlalu lama dipanaskan. Sehingga spesimen tanpa perlakuan curing mendapat hasil pengujian bending yang paling tinggi. Pada proses curing hasil pengujian bending yang paling baik terdapat pada perlakuan curing suhu $80^{\circ} \mathrm{C}$ dengan waktu perlakuan curing 1 jam didapatkan hasil sebesar 840.915 Mpa. Sedangkan pengujian paling terendah yaitu pada perlakuan curing $80^{\circ} \mathrm{C}$ dengan waktu perlakuan curing 3 jam didapatkan hasil sebesar 1008.670 Mpa. Perbedaan temperature curing pada pengujian banding komposit serat karbon- resin berpengaruh pada nilai tegangan banding. Semakin besar suhu curing mendapatkan hasil semakin getas pada komposit serat karbon-resin.

3. Dari foto makro spesimen hasil pengujian tarik yang diberikan perlakuan curing pada waktu 1 jam, 1,5 jam, 2 jam, 2,5 jam dan 3 jam dapat dilihat bahwa foto patahan terlihat rapi pada perlakuan curing 1,5 jam. komposit serat karbon-resin banyak mengalami perbedaan mulai dari hasil patahan, perubahan warna spesimen dan penyusutan spesimen saat di beri perlakuan curing.

4. Densitas komposit yang diberikan perlakuan curing pada waktu 1 jam , 1,5 jam, 2 jam, 2,5 jam dan 3 jam dengan penahanan suhu $80^{\circ} \mathrm{C}$ mengalami perubahan pengaruh curing terhadap densitas, hasil tertinggi yang dihasilkan pengaruh curing terhadap densitas pada waktu 2 jam didapat hasil sebesar 1,393 $\mathrm{gr} / \mathrm{cm} 3$.

\section{DAFTAR PUSTAKA}

ASTM. (2003). Annual Book of ASTM Standard. West Conshohocken.

Jones, R, M. (1975). Mechanics of Composite Materials. Scripta Book Company.

K. Van Rijswijk, M.Sc., et. al. (2001). Natural Fiber Composite Structures and Materials (Laboratory).

Kaw, A. K. (2006). Mechanics of composite materials (Mechanical). Taylor \& Francis.

http://dl.merc.ac.ir/handle/Hannan/3343

Korompis, B., Rahmat, A. R., Heatley, F., \& Day, R. J. (2003). Pengaruh Temperatur Curing Terhadap Kekuatan Tarik 
Komposit Unsaturated Polyester Resin Yang Diperkuat Serat Pisang. 32(6), 257-264.

Kroschwitz J L., G. (1987). Encyclopedie of Polymer Science and Engineering. John Wiley and Sons, 2nd ed.(Inc. New York.).

M. M. Schwartz. (1984). Composite Materials Handbook, McGraw-Hill Book Company, New York.

Nurcahyo dkk. 2004, menguji variasi temperature curing yang dapat membuat kekuatan tarik menjadi optimal.

Surdia, Tata. Saito., 2000 Pengetahuan Bahan Teknik. Jakarta: Pradnya Pramita.

Schwartz, M.M., 1984.’Composite Materials Handbook". McGraw-Hill. New York.

Wijoyo, Achmad N., 2014, Kajian Komprehensif Kekuatan Bending Komposit Sandwich Serat ArenPolyester Dengan Core Gedebog Pohon Pisang, Jurnal Teknologi, Vol. 7, No. 4, Hal 128-123.

Wijaya. (2006). Pengaruh Suhu Curing Terhadap Sifat Mekanis dan Fisis Komposit Polimer (E-glass dan Arindo 3210). 